\title{
Diversity and seasonal dynamics of airborne archaea
}

\author{
J. Fröhlich-Nowoisky ${ }^{1}$, C. Ruzene Nespoli ${ }^{1}$, D. A. Pickersgill ${ }^{1,2}$, P. E. Galand ${ }^{3,4}$, I. Müller-Germann ${ }^{1,5}$, T. Nunes ${ }^{6}$, \\ J. Gomes Cardoso ${ }^{6,7}$, S. M. Almeida ${ }^{8}$, C. Pio ${ }^{6}$, M. O. Andreae ${ }^{1}$, R. Conrad ${ }^{9}$, U. Pöschl ${ }^{1}$, and V. R. Després ${ }^{2}$ \\ ${ }^{1}$ Max Planck Institute for Chemistry, P.O. Box 3060, 55020 Mainz, Germany \\ ${ }^{2}$ Institute of General Botany, Johannes Gutenberg University, Johannes-von-Müller-Weg 6, 55128 Mainz, Germany \\ ${ }^{3}$ UPMC, Univ Paris 06, Observatoire Océanologique, Banyuls-sur-Mer, France \\ ${ }^{4}$ CNRS, UMR8222, Laboratoire d'écogéochimie des environnements benthiques, Observatoire Océanologique, \\ Banyuls-sur-Mer, France \\ ${ }^{5}$ Geosciences, Johannes Gutenberg University, Joh.-Joachim-Becher-Weg 21, 55128 Mainz, Germany \\ ${ }^{6}$ CESAM \& Department of Environment, University of Aveiro, 3810-193 Aveiro, Portugal \\ ${ }^{7}$ University of Cape Verde, 279 CPraia, Santiago, Cape Verde \\ ${ }^{8}$ C2TN, Instituto Superior Técnico, Universidade de Lisboa, EN10, 139.7 km, 2695-066 Bobadela LRS, Portugal \\ ${ }^{9}$ Max Planck Institute for Terrestrial Microbiology, Karl-von-Frisch-Straße 10, 35043 Marburg, Germany \\ Correspondence to: V. R. Després (despres@uni-mainz.de) and J. Fröhlich-Nowoisky (j.frohlich@mpic.de)
}

Received: 25 April 2014 - Published in Biogeosciences Discuss.: 16 May 2014

Revised: 11 September 2014 - Accepted: 24 September 2014 - Published: 11 November 2014

\begin{abstract}
Archaea are widespread and abundant in many terrestrial and aquatic environments, and are thus outside extreme environments, accounting for up to $\sim 10 \%$ of the prokaryotes. Compared to bacteria and other microorganisms, however, very little is known about the abundance, diversity, and dispersal of archaea in the atmosphere. By means of DNA analysis and Sanger sequencing targeting the $16 \mathrm{~S}$ rRNA (435 sequences) and amoA genes in samples of air particulate matter collected over 1 year at a continental sampling site in Germany, we obtained first insights into the seasonal dynamics of airborne archaea. The detected archaea were identified as Thaumarchaeota or Euryarchaeota, with soil Thaumarchaeota (group I.1b) being present in all samples. The normalized species richness of Thaumarchaeota correlated positively with relative humidity and negatively with temperature. This together with an increase in bare agricultural soil surfaces may explain the diversity peaks observed in fall and winter. The detected Euryarchaeota were mainly predicted methanogens with a low relative frequency of occurrence. A slight increase in their frequency during spring may be linked to fertilization processes in the surrounding agricultural fields. Comparison with samples from the Cape Verde islands (72 sequences) and from other coastal and continental sites indicates that the proportions of Euryarchaeota are enhanced in coastal air, which is consistent with their
\end{abstract}

suggested abundance in marine surface waters. We conclude that air transport may play an important role in the dispersal of archaea, including assumed ammonia-oxidizing Thaumarchaeota and methanogens.

\section{Introduction}

Archaea have long been thought to occur only in restricted, extreme environments. However, since their formal recognition as an independent domain of life about two decades ago (Woese et al., 1990), they have been found in a wide variety of habitats from hydrothermal vents to aquatic and soil environments (Auguet et al., 2010; Bintrim et al., 1997; Boetius et al., 2000; Jurgens et al., 2000; Ochsenreiter et al., 2003; Schleper et al., 1997; Takai et al., 2001). Archaea are now known to be abundant, diverse, and widespread organisms that act as major players in the nitrogen and carbon cycle (Offre et al., 2013; Pester et al., 2012; Schleper et al., 2005).

Despite the recognition of the ubiquitous nature of archaea, their possible presence in the atmosphere is poorly investigated. While the atmosphere may not be a key habitat of archaea, it may act as the primary medium for the dispersal of microorganisms among the different ecosystems on the Earth's surface (Fröhlich-Nowoisky et al., 2012). For other 
bioaerosols such as bacteria and fungi, studies have been conducted that describe the composition, diversity, abundance, seasonal, and even daily variation of these organisms in the atmosphere, and explore their distribution and biogeography (e.g., Després et al., 2012; Fröhlich-Nowoisky et al., 2012; and references therein). These matters are still unanswered for archaea.

The few published reports on airborne archaea are from anthropogenic environments such as compost piles or biosolids (e.g., Baertsch et al., 2007; Moletta et al., 2007; Thummes et al., 2007) and a handful of natural and urban environments (Bowers et al., 2013; Brodie et al., 2007; Cao et al., 2014; Cho and Hwang, 2011; Radosevich et al., 2002; Robertson et al., 2013; Smith et al., 2013; Yooseph et al., 2013). The extent of these studies remains very limited, and the number of airborne archaea sequences presented in the literature is small. Thus, the first insights into the presence of archaea in the atmosphere could draw only very preliminary conclusions about the composition from single sites and specific sampling times. In particular, nothing is known about which metabolic groups of archaea are present in the air.

Archaea have various types of metabolisms, some of which are involved in key biogeochemical processes like the production of methane, the assimilation of amino acids, or the oxidation of ammonia (Cavicchioli, 2011; Pester et al., 2011). Nitrification is a central process of the global nitrogen cycle that can be divided into two steps: the oxidation of ammonia to nitrite and the oxidation of nitrite to nitrate. Ammonia-oxidizing bacteria and archaea (AOB and AOA, respectively) use the enzyme ammonia monooxygenase (encoded by the amoA gene; Falkowski et al., 2008; Gruber and Galloway, 2008; Kowalchuk and Stephen, 2001) to perform the conversion to nitrite, which is the rate-limiting step. Since the discovery of the importance of the amoA gene, it has been widely used to explore the diversity and abundance of AOA, even though the presence of the gene does not necessarily prove the potential for ammonia oxidation (Pester et al., 2011). Thus, amoA-gene-based studies have allowed for a better understanding of the ecological and evolutionary factors shaping the community assembly in AOA and the factors that drive community distribution (Auguet et al., 2010; Cao et al., 2011; Cavicchioli, 2011).

The main purpose of this study was first to determine whether airborne archaea are present all year round, and whether they display seasonal dynamics. Furthermore, we wanted to test the hypothesis of whether the composition of airborne archaea depends on the type of ecosystem found below the air masses. For the first purpose, we gathered samples for 1 year in continental boundary layer air at one sampling site and identified archaeal communities by sequencing the 16S rRNA and the amoA gene. For the second objective, we compared the results of the continental air site with discrete sampling from other geographical regions, including both coastal and continental air, to understand the composi- tion of airborne archaea under both a local and a more global perspective.

\section{Material and methods}

\subsection{Aerosol sampling}

As it is well established that decontamination of sampling devices is a necessary prerequisite for reliable molecular genetic analysis (Després et al., 2007), the quartz and glass fiber filters used were baked at high temperatures to eliminate possible biological traces. To secure a continuous quality assurance, we regularly cleaned the samplers with ethanol to prevent colony growth in the interiors and checked the air flow rates weekly. For some sampling sites (e.g., Germany), we separated the particles into coarse and fine mode, while for other sites or campaigns (e.g., North America) total suspended particulate matter was analyzed. As small variations occur between the different sampling sites within the sampling strategies, the specific details are given per site. With the main analyses focusing on the samples from Germany and Cape Verde only, the detailed sampling strategies for these sites are presented here; the information for the other sites is available in the Supplement. However, for an overall comparison, the main sampling information is listed in Table 1 and Supplement Table S1.

\subsubsection{Germany}

Over 1 year, 47 pairs of fine and coarse particle samples were collected in Mainz, Germany (March 2006-April 2007). A self-built high-volume dichotomous sampler (Solomon et al., 1983) was used, which was operated with a rotary vane pump (Becker VT 4.25) at a total flow rate of $\sim 0.3 \mathrm{~m}^{3} \mathrm{~min}^{-1}$, corresponding to a nominal cutoff diameter of $\sim 3 \mu \mathrm{m}$. Thus, coarse particles with an aerodynamic diameter larger than $\sim 3 \mu \mathrm{m}$ were collected on one glass fiber filter $\left(\sim 0.03 \mathrm{~m}^{3} \mathrm{~min}^{-1}\right)$, while the fine particles from the same air sample were collected on a second glass fiber filter $\left(\sim 0.27 \mathrm{~m}^{3} \mathrm{~min}^{-1}\right)$. The sampling period was generally $\sim 7$ days, corresponding to a sampled air volume of $3000 \mathrm{~m}^{3}$. A few samples were collected over shorter periods (volumes of $\left.\sim 400-2000 \mathrm{~m}^{3}\right)$. The sampling station was positioned on a mast about $5 \mathrm{~m}$ above the flat roof of the three-storyhigh Max Planck Institute for Chemistry building (MPIC) on the campus of the University of Mainz (49 $59^{\prime} 31.36^{\prime \prime} \mathrm{N}$, $\left.8^{\circ} 14^{\prime} 15.22^{\prime \prime} \mathrm{E}\right)$. The sampled air masses represent a mix of urban and rural continental boundary layer air in central Europe. All glass fiber filters were baked overnight at $500^{\circ} \mathrm{C}$ prior to sampling, and the loaded filters were sealed in decontaminated aluminum foil and stored at $-80^{\circ} \mathrm{C}$ until analysis.

To detect possible contaminants from the sampler and sample handling, blank samples were taken at 4-week intervals. Prebaked filters were mounted in the sampler like for 
Table 1. Overview and diversity parameters of aerosol filter samples and detected archaea. Sampling details of continental and coastal sites are given: number of air samples, aerosol size range (total suspended particles (TSP) and particulate matter (PM)), and obtained number of DNA sequences. Statistical parameters: species richness ( $S$ measured, $S^{*}$ estimated), Shannon index $\left(H^{\prime}\right)$, Shannon evenness $(E)$, and Simpson's index $(D)$, not available (n.a.; see also Table S3). The measured species richness $S$ in North America, China, and UK needs to be interpreted with caution as only few sequences were available.

\begin{tabular}{|c|c|c|c|c|c|}
\hline \multirow[b]{2}{*}{ Sampling region } & \multicolumn{2}{|c|}{ Continental } & \multicolumn{3}{|c|}{ Coastal } \\
\hline & Germany & North America & Cape Verde & China & UK \\
\hline Elevation & $130 \mathrm{~m}$ & $2370 \mathrm{~m}$ & $69 \mathrm{~m}$ & $21 \mathrm{~m}$ & $0 \mathrm{~m}$ \\
\hline Above ground & $20 \mathrm{~m}$ & $1 \mathrm{~m}$ & $14 \mathrm{~m}$ & $1.5 \mathrm{~m}$ & $40 \mathrm{~m}$ \\
\hline Latitude & $49^{\circ} 59^{\prime} 31.36^{\prime \prime} \mathrm{N}$ & $39^{\circ} 6^{\prime} 0^{\prime \prime} \mathrm{N}$ & $14^{\circ} 55^{\prime} 33.96^{\prime \prime} \mathrm{N}$ & $23^{\circ} 32^{\prime} 52.7994^{\prime \prime} \mathrm{N}$ & $52^{\circ} 57^{\prime} 02^{\prime \prime} \mathrm{N}$ \\
\hline Longitude & $8^{\circ} 14^{\prime} 15.22^{\prime \prime} \mathrm{E}$ & $105^{\circ} 5^{\prime} 30^{\prime \prime} \mathrm{W}$ & $-23^{\circ} 29^{\prime} 40.92^{\prime \prime} \mathrm{W}$ & $113^{\circ} 3^{\prime} 57.6^{\prime \prime} \mathrm{E}$ & $1^{\circ} 07^{\prime} 19^{\prime \prime} \mathrm{E}$ \\
\hline Samples & 47,47 & 20 & 26 & 14 & 12 \\
\hline $\begin{array}{l}\text { Sampling } \\
\text { duration }\end{array}$ & $\begin{array}{l}\text { Mar 2006- } \\
\text { Apr } 2007\end{array}$ & July 2011 & $\begin{array}{l}\text { Feb 2011- } \\
\text { Mar } 2011\end{array}$ & Jul 2006 & spring 2004 \\
\hline Filter type & glass & glass & quartz & quartz & glass \\
\hline Average flow rate & $0.3 \mathrm{~m}^{3} \mathrm{~min}^{-1}$ & $1 \mathrm{~m}^{3} \mathrm{~min}^{-1}$ & $1 \mathrm{~m}^{3} \min ^{-1}$ & $1 \mathrm{~m}^{3} \min ^{-1}$ & $1.120 \mathrm{~m}^{3} \mathrm{~min}^{-1}$ \\
\hline Size range & $<3 \mu \mathrm{m},>3 \mu \mathrm{m}$ & TSP & $\mathrm{PM}_{10}$ & TSP & $<4.49 \mu \mathrm{m}$ \\
\hline Sequences & 435 & 20 & 72 & 7 & 11 \\
\hline$S$ & 57 & 1 & 25 & 1 & 4 \\
\hline$S^{*}$ & 137 & n.a. & 67 & n.a. & n.a. \\
\hline$H^{\prime}$ & 3.32 & n.a. & 3.07 & n.a. & n.a. \\
\hline$E$ & 0.82 & n.a. & 0.95 & n.a. & n.a. \\
\hline$D$ & 0.05 & n.a. & 0.05 & n.a. & n.a. \\
\hline
\end{tabular}

regular sampling, but the pump was either not turned on at all ("mounting blanks") or only for $5 \mathrm{~s}$ ("start-up blank").

\subsubsection{Cape Verde}

Filter sampling was part of the Cape Verde Dust project (CVDust). The sampling station was positioned $\sim 1500 \mathrm{~m}$ from the coast at $69 \mathrm{~m}$ elevation, latitude $14^{\circ} 55^{\prime} 33.96^{\prime \prime} \mathrm{N}$, longitude $23^{\circ} 29^{\prime} 40.92^{\prime \prime} \mathrm{W}$. For the 26 Cape Verde samples (Table 1 and Supplement Table S1), Whatman quartz filters were used and sampling was done between February and March 2011 with a PM $_{10}$ high-volume sampler (Tisch PM10, TE6001) placed $14 \mathrm{~m}$ above ground level and with a flow rate of $1 \mathrm{~m}^{3} \mathrm{~min}^{-1}$. Sampling periods ranged from less than $24 \mathrm{~h}$ to 3 days. Prior to sampling, filters were decontaminated by baking for $6 \mathrm{~h}$ at $500^{\circ} \mathrm{C}$, and after sampling they were stored in decontaminated bags and kept frozen at $-80^{\circ} \mathrm{C}$ until DNA extraction. The air at this site is primarily coastal with influence from continental air masses, which may carry particles from Saharan or Sahel dust events.

\subsection{DNA extraction and amplification}

Filter sample aliquots (about $1-25 \%$ of the filter) were extracted with a commercial soil DNA extraction kit (Lysing Matrix E, FastDNA SPIN Kit for Soil, MP Biomedicals) according to the supplier's instructions with the following modifications (depending on the character of the filter): centrifugation (10-15 min) after the lysis, followed by addition of $900 \mu \mathrm{L}$ buffer provided by the extraction kit and a sec- ond round of beating and centrifugation. The supernatants of both extraction steps were combined for the further extraction process. Finally, the DNA was dissolved in $100 \mu \mathrm{L}$ elution buffer. Decontaminated filters were included during the extractions as extraction blanks. Extraction blanks without filters were prepared as well.

For the laboratory work, regular quality control and assurance measurements were taken. All polymerase chain reactions (PCRs) were set up with sterile equipment in a DNAfree environment. As it was difficult to amplify airborne archaea (see also Supplement), we used three primer pairs as well as nested primers to increase the amplification success. Thus, with the DNA extract from each of the filters, up to four PCRs were performed using normal and nested primer pairs targeting the $16 \mathrm{~S}$ rRNA gene. The number of PCRs was dependent on the successful amplification. To detect even minimal amounts of archaeal DNA, an additional PCR and eventually nested PCRs were only performed if the first PCR failed. The $25-50 \mu \mathrm{L}$ reaction mixture contained the template DNA $(0.5-1 \mu \mathrm{L}$ sample extract), $1 \times$ PCR buffer, $0.2 \mathrm{mM}$ each dNTP (Roth), $0.33 \mu \mathrm{M}$ each primer (Sigma Aldrich), $2 \mathrm{mM} \mathrm{MgCl}{ }_{2}$, and 2.5 units of JumpStart REDTaq DNA polymerase. A negative control was included in all PCR runs.

The thermal profile of the 16S PCR was as follows: initial denaturing at $94^{\circ} \mathrm{C}$ for $3 \mathrm{~min}, 34$ cycles with $94^{\circ} \mathrm{C}$ for $30 \mathrm{~s}$, annealing at $55^{\circ} \mathrm{C}$ for $1 \mathrm{~min}$ for primer pair $\mathrm{A} 2 \mathrm{~F} / 958 \mathrm{r}$ (Baker and Cowan, 2004; Wani et al., 2006) or at $52^{\circ} \mathrm{C}$ for $20 \mathrm{~s}$ for primer pair 109f/934r (Grosskopf et al., 1998), elongation at $72{ }^{\circ} \mathrm{C}$ for $1.5 \mathrm{~min}$, and a final extension step 
at $72^{\circ} \mathrm{C}$ for $5 \mathrm{~min}$. Nested PCRs were done with primer pair 109f/934r and primer pair 109f/927r (Baker and Cowan, 2004; Grosskopf et al., 1998), respectively. The thermal profile for both pairs was as follows: initial denaturing at $94{ }^{\circ} \mathrm{C}$ for $2 \mathrm{~min}, 29$ cycles with $94^{\circ} \mathrm{C}$ for $30 \mathrm{~s}$, annealing at $52^{\circ} \mathrm{C}$ for $1 \mathrm{~min}$, elongation at $72^{\circ} \mathrm{C}$ for $1 \mathrm{~min}$, and a final extension at $72{ }^{\circ} \mathrm{C}$ for $10 \mathrm{~min}$. A contamination occurred within one extraction blank in the samples of Cape Verde. The PCR product was cloned and sequenced and the sequences grouped into operational taxonomic units (OTUs). The OTUs occurring in this extraction blank PCR were completely removed from the analysis, and thus also from any other filter sample.

An $a m o A$ analysis was performed for 18 coarse filters from Mainz, Germany (Table S1). For the archaeal amoA gene, the primer pair amo19F-amo643R with the nested primer pair amo111F-amo643R was used (Leininger et al., 2006; Treusch et al., 2005). The PCR mix was as described above. The PCR consisted of an initial denaturation at $94^{\circ} \mathrm{C}$ for $4 \mathrm{~min}, 9$ cycles at $94^{\circ} \mathrm{C}$ for $45 \mathrm{~s}$, annealing at $55-65^{\circ} \mathrm{C}$ for $1 \mathrm{~min}$, elongation at $72^{\circ} \mathrm{C}$ for $1 \mathrm{~min}$ and 19 cycles at $94^{\circ} \mathrm{C}$ for $45 \mathrm{~s}, 55^{\circ} \mathrm{C}$ for $1 \mathrm{~min}$ and $72{ }^{\circ} \mathrm{C}$ for $1 \mathrm{~min}$, and a final extension step at $72{ }^{\circ} \mathrm{C}$ for $10 \mathrm{~min}$.

Amplification products of each filter sample selected for sequencing were cloned using the TOPO TA Cloning Kit (Invitrogen) following the supplier's instructions. Colonies containing inserts were identified by blue-white selection and lysed in $20 \mu \mathrm{L}$ water for $10 \mathrm{~min}$ at $95^{\circ} \mathrm{C}$. The cloning efficiency was between 5 and 200 colonies per cloned PCR product. The inserts of 12-24 randomly picked colonies were amplified for each PCR product using $1.5-3 \mu \mathrm{L}$ lysate in a $25-40 \mu \mathrm{L}$ reaction. If fewer colonies were available, all colonies were amplified and sequenced.

\subsection{Sequence and phylogenetic analysis}

DNA sequences were determined with ABI Prism 377, 3100 , and 3730 sequencers (Applied Biosystems) using BigDye Terminator v3.1 chemistry at the Max Planck Genome Centre, Cologne. To assure quality, we studied the individual chromatograms for background noise and cut the vector sequences. Sequences were screened for possible chimera using the Bellerophon program (Huber et al., 2004). The alignment was conducted using the MUSCLE (multiple sequence comparison by log expectation) package (Edgar, 2004) and thereafter manually checked. The taxonomic identification was only based on sequence data. The sequences from each sampling site were clustered into OTUs, which represent artificial species. For the 16S rRNA sequence, the similarity of sequences within a species is thought to be at least $97 \%$ (Stackebrandt and Goebel, 1994). As the PCR products can be inserted during the cloning process into the vector sequence in both directions and the sequencing was conducted from one direction, the reads sometimes cover different sections of the analyzed sequence or they only have a few base pairs of overlap. Thus, for the identification of
OTUs, sequences were grouped together according to their sequence coverage to provide the longest possible length for an automatic analysis with the Mothur software package (Schloss et al., 2009). Sequence blocks were cut to the longest possible length to retain as many sequences as possible. For Germany this was $\sim 370$ base pairs (bp), for North America $\sim 470$, for China $\sim 600$, and for the UK $\sim 760$. Sequences that were too short for the chosen blocks were compared manually to the other sequences to determine whether they fitted into one of the automatically identified OTUs or formed a new one. OTUs and their reference sequences were determined with the Mothur package. For the sequences from Cape Verde, OTUs were created by using the USEARCH v5.2.3.2 package (Edgar, 2010) at the $97 \%$ discrimination level and manual BLAST procedures.

For the phylogenetic identification of the OTUs, two approaches were used. Firstly, a broad taxonomic identification by comparing the sequences of interest with the sequences in well-known databases and, secondly, a more detailed analysis by calculating phylogenetic trees. The results from the comparison against databases were used to identify potentially closely related archaea strains. From these strains we then used type species to build a basic tree for the phylogenetic tree analysis. The basic tree sequences are listed in Table S2.

For these comparisons, with known sequences, both the Basic Local Alignment Search Tool (BLAST), via the website of the National Center for Biotechnology Information (NCBI, http://www.ncbi.nlm.nih.gov/), and the SINA aligner (Pruesse et al., 2012), which includes several microbial databases, were used.

For the phylogenetic analysis, a basic tree was constructed that mainly included sequences from cultured, identified type species and a few from uncultured species (Table S2). For identification the representative sequences of each OTU were then included. For OTUs where the representative sequences did not overlap the area used for the tree calculation, the best match sequences were used as placeholders, but only when the similarity between the sequence and its best match was higher than $97 \%$. The model of evolution best suitable for the sequence sets was chosen using the "find best DNA/protein model" option in Mega5.2.2 (Tamura et al., 2011). Phylogenetic trees were constructed by means of the maximum likelihood algorithm using Tamura's three-parameter substitution model with gamma distributed rates for the analysis of the $16 \mathrm{~S}$ sequences and 1000 replicates for the boot strap values. Additionally, we also tested the neighbor-joining algorithm, which agreed with maximum likelihood results.

The amoA gene DNA sequences were likewise aligned with MUSCLE. OTUs were formed when the sequence similarity scores were $>85 \%$ according to Pester et al. (2012). Phylogenetic trees were built on the nucleotide level based on Tamura's three-parameter model as described above and on the amino acid level using the $\mathrm{WAG}+\mathrm{G}+\mathrm{F}$ model (Whelan and Goldman, 2001). 
The sequences of the present study have been deposited in the GenBank database under the following accession numbers: for 16S rRNA genes KF683446-KF683516 (Cape Verde), KF558331-KF558337 (China), JQ249390-JQ249751 (Germany), JQ976019-JQ976037 (North America), KF558321-KF558330 (United Kingdom), and for the amoA gene sequences (KF824904-KF824908).

\subsection{Quantitative PCR assays}

All quantitative PCR (qPCR) reactions were performed on an iCycler thermocycler equipped with a MyiQ detection system (Bio-Rad, Munich, Germany) and the data were analyzed using the iQ3 Optical System software (Bio-Rad). As a standard for archaea, a pure culture of Methanosarcina thermophila was used (Lueders et al., 2004), and for the bacteria, chromosomal DNA of Escherichia coli K12 (Stubner, 2002) was used. Both standards were serially diluted and used for the construction of calibration curves in each reaction. Duplicates were analyzed for the standards, and triplicates for the filter extracts.

For the actual quantification process the following primer pairs were chosen: for archaea 364f (5'-CGG GG(CT) GCA (GC)CA GGC GCG AA- $\left.3^{\prime}\right)$ and 934r (5'-GTG CTC CCC CGC CAA TTC CT-3') and for bacteria 519f (5'-CAG C(AC)G CCG CGG TAA (AGCT) (AT)C-3') and 907f/926r (5'-CCG TCA ATT CMT TTR AGT TT-3'), as commonly used (Burggraf et al., 1997; Grosskopf et al., 1998; Lane, 1991). The qPCR assays were based on SYBR Green (Ambion). Each reaction had a volume of $25 \mu \mathrm{L}$ and the following mixture for archaea (conditions for bacteria in brackets): $12.5 \mu \mathrm{L}$ SYBR Green JumpStart Taq ReadyMix, 1.5 (4) mM $\mathrm{MgCl}_{2}, 0.66(0.5) \mu \mathrm{M}$ of each primer, and $5 \mu \mathrm{L}$ of the template DNA and $1 \mu \mathrm{M}$ FITC. For the assay, the program used was as follows: $94^{\circ} \mathrm{C}$ for one cycle for $6(8) \mathrm{min}$, followed by $45(50)$ cycles at $94^{\circ} \mathrm{C}$ for $35 \mathrm{~s}(20 \mathrm{~s}), 66^{\circ} \mathrm{C}\left(50^{\circ} \mathrm{C}\right)$ for $30 \mathrm{~s}(20 \mathrm{~s}), 72^{\circ} \mathrm{C}$ for $45 \mathrm{~s}(50 \mathrm{~s})$, and $85.5^{\circ} \mathrm{C}\left(75^{\circ} \mathrm{C}\right)$ for $6 \mathrm{~s}$ for signal reading.

\subsection{Statistical analysis}

Although the number of the here analyzed Sanger sequences is low compared to modern next-generation sequencing techniques, we performed statistical analyses to get a first indication of species richness and possible correlations with meteorological conditions. However, species richness measurements were only performed for the sites with most sequences (Germany and Cape Verde). Correlation analyses with meteorological conditions were only performed for Germany, where most sequences were analyzed.

To assess whether there were significant correlations between the diversity of sampled archaea and the meteorological factors, the relative species richness per sample $j\left(S_{R, j}\right)$, as well as the relative species richness per month $k\left(S_{R, k}\right)$, was calculated (see Table S3). The statistical analysis was performed using the R package (R Development Core Team, 2005). Pearson's linear regression coefficients were calculated between the relative species richness and the sampling period or monthly averages for temperature, relative humidity, and wind speed, as well as for the sum of precipitation per sample, to assess the influence of the single factors on the sampled diversity.

To examine whether a combination of meteorological factors correlates best with the sampled diversity, the stepwise AIC method (Akaike information criterion) for variable selection (Yamashita et al., 2007) was conducted. A more detailed linear regression analysis (Neter et al., 1996) was then performed on the best results of the Pearson and stepwise AIC test. A more detailed description of the analysis can be found in the Supplement.

\section{Results and discussion}

\subsection{Abundance and diversity of airborne archaea in continental boundary layer air}

From the 47 air filters sampled at Mainz, Germany (Table S1), we retrieved a total of 435 archaeal 16S rRNA gene sequences that grouped into 57 OTUs. The aerosols at this site were sampled by means of size selection with a cut point at $3 \mu \mathrm{m}$. Archaea sequences could be amplified in all coarse samples $(>3 \mu \mathrm{m})$, but only in $21 \%$ of the fine particle filter samples $(<3 \mu \mathrm{m})$. To better understand this phenomenon, we quantified copies (cp) of archaea and bacteria 16S rRNA genes in a subset of six air filter samples. We found the abundance of archaea in air to be only between $\sim 1$ and $\sim 10$ gene copies per cubic meter of air, while that of bacteria was found to be $\sim 10^{4}$ to $\sim 10^{6}$ in the same air samples (Table S4). These results are strikingly different from observations in soil and ocean surface water, where archaea represent about $10 \%$ of the total prokaryotic abundance (Bates et al., 2011; Cao et al., 2012; DeLong, 1992; Karner et al., 2001; Kemnitz et al., 2007; Yin et al., 2013). One of the explanations might be that archaea could be more susceptible to UV light or other damage caused by, for example, components from the fine aerosol than bacteria. However, the fact that archaea were more numerous in coarse particle filters may indicate that archaea are often attached to soil dust particles as it also has been shown for bacteria (Jones and Harrison, 2004). The observation that archaea are more difficult to amplify than other airborne microbes has been stated in other publications as well (Bowers et al., 2009, 2013; Fierer et al., 2008; Woo et al., 2013; Woo, 2012).

This study gives first insights that airborne archaea were present all year long in air from the continental boundary layer. Bioaerosols in air have a lifetime of about a week (Burrows et al., 2009), implying that the aerosols sampled may have traveled several thousand kilometers. Therefore, this study's data represent not only a snapshot of the actual 

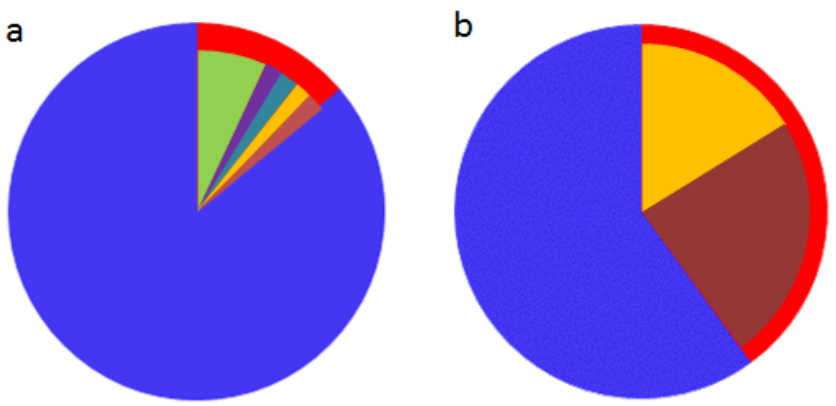

Euryarchaeota
Thaumarchaeota

Halobacteriales

Thermoplasmatales

Figure 1. Species richness of airborne archaea. Relative proportions of different phyla (Thaumarchaeota and Euryarchaeota) and, within the Euryarchaeota, of different orders for continental air, Mainz (a), and coastal air, Cape Verde (b), respectively.

diversity but also include information about possible sources and distribution patterns.

All archaeal 16S rRNA gene OTUs at the German sampling site belonged either to Euryarchaeota (14\%) or Thaumarchaeota (86\%; see also Fig. 1a and Supplement Fig. S1, Table S5). Thaumarchaeota are widespread on Earth (Pester et al., 2011) and are detected in various environments such as freshwater, ocean, sediments, and hot springs, with an especially high abundance in soil (Bates et al., 2011; BrochierArmanet et al., 2008, 2011; Leininger et al., 2006; Ochsenreiter et al., 2003; Schleper and Nicol, 2010). Based on phylogenetic analysis, all OTUs of the Thaumarchaeota were affiliated with the 16S rRNA sequences from the soil group I.1b (Fig. S1, Table S5). Group I.1b archaea were composed of a high number of related phylotypes (Fig. S1), similar to what is observed in soils (Auguet et al., 2010).

In addition to the $16 \mathrm{~S}$ rRNA gene, the phylogenetic relationships of the amoA gene, which is used as a reliable marker to study the diversity of archaeal ammonia oxidizers, was also analyzed (Cao et al., 2011, 2013; Junier et al., 2010). The amoA gene was successfully detected on a subset of 18 coarse particulate matter samples, spanning all four seasons (Table S1). The 176 archaeal amoA sequences grouped into 5 OTUs. Thus, the diversity of archaeal amoA genes was lower than that of archaeal $16 \mathrm{~S}$ rRNA genes. Strengthening the results from the analysis of archaeal 16S rRNA OTUs, all amoA OTUs belonged to the genus Nitrososphaera, affiliated with the group I.1b of soil archaea identified using the nucleotide (Fig. 2) and the amino acid sequences. Both findings support observations made for airborne bacteria showing that airborne microbial diversity is closely linked to soil diversity, and that soil and soil

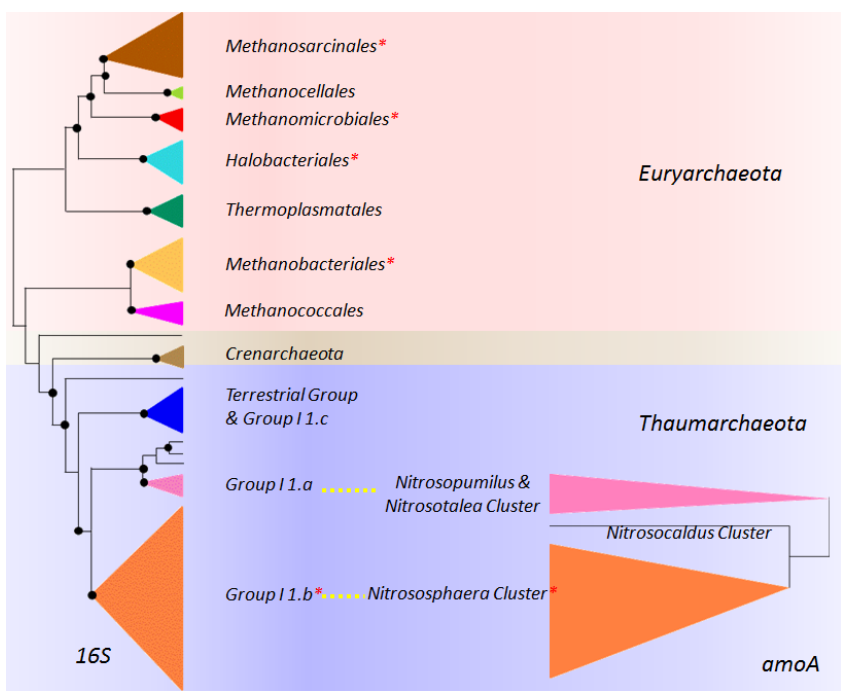

Figure 2. Phylogeny of Euryarchaeota and predicted ammoniaoxidizing Thaumarchaeota. Schematic illustration of a collapsed maximum likelihood tree based on the OTU sequences found in Mainz, Germany, in the 16S rRNA gene (left) and archaeal amoA gene (right), as well as basic tree sequences (Table S2). Black dots represent boot strap values $>80 \%$. Red stars indicate where OTUs from airborne archaea (Mainz, Germany) fall. The amoA cluster names are given according to Pester et al. (2012); the figure has been laid out as in Pester et al. (2011).

dust might be a primary source of airborne microorganisms (Brodie et al., 2007; Després et al., 2007, 2012; Fierer et al., 2008; Jones and Harrison, 2004; Lighthart and Shaffer, 1995; Prospero et al., 2005).

In comparison to Thaumarchaeota, the number of OTUs of Euryarchaeota was low. Euryarchaeotal 16S rRNA gene sequences were present in $32 \%$ of the samples and attributed to five well-known orders. Halobacteriales, Thermoplasmatales, Methanomicrobiales and Methanosarcinales were represented by a single OTU each, while $50 \%$ of the OTUs belonged to the Methanobacteriales (Figs. 1a and S1, Table S5). The presence of predicted methanogens may be surprising, as Ochsenreiter et al. (2003) suggested that oxic soils support only the Thaumarchaeota group I.1b. However, a recent study by Angel et al. (2012) proved that methanogenic Euryarchaeota, despite being obligate anaerobic, are present in oxic soils and regain their methanogenesis activity when deprived of oxygen. Other studies finding methanogens in soil attributed their presence to the effect of livestock introducing methanogens into the soil with their feces (Gattinger et al., 2007; Nicol et al., 2003; Radl et al., 2007). Similar to Thaumarchaeota, Euryarchaeota in air are likely to originate from aerosolized soil or other emission sources.

Thaumarchaeota had a normalized species richness $\left(S_{n}\right.$, number of detected OTUs divided by number of investigated samples; Table S3) of approx. 2 to 3 throughout the year (Fig. 3a), with OTU Archl being the most frequent 


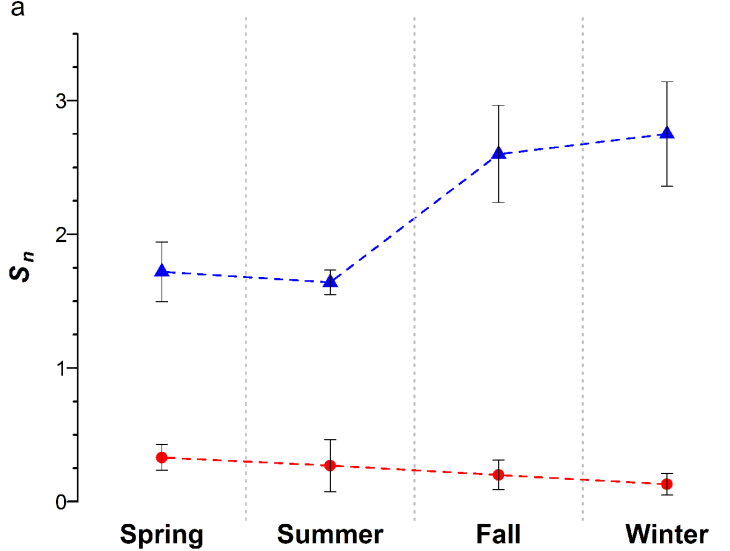

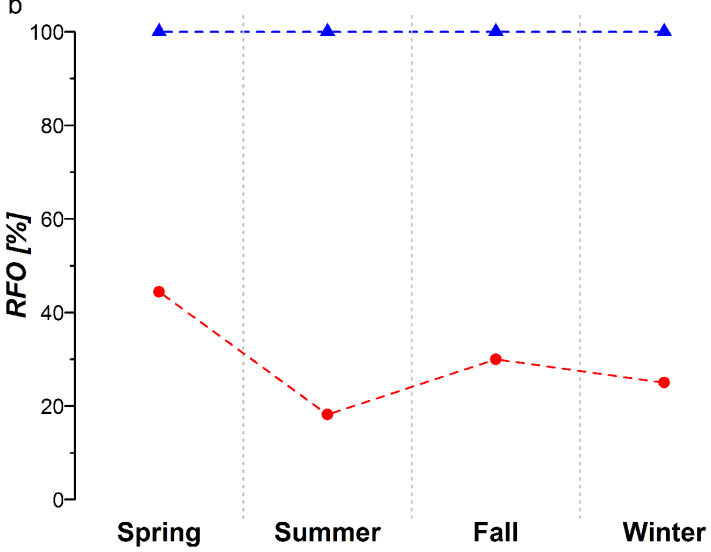

-.- Thaumarcheaota--- Euryarchaeota

Figure 3. Overview of the species richness in Mainz. Seasonal variations in the species richness of Euryarchaeota and Thaumarchaeota in total suspended particles (TSP) normalized by the number of investigated air samples (a) and in the relative frequency of occurrence (RFO) of the phyla Euryarchaeota and Thaumarchaeota in Mainz, Germany (b).

OTU present in $70 \%$ of the samples. In contrast, the $S_{n}$ of Euryarchaeota was always below 1, and the two most frequent OTUs (Arch12 and Arch13) were detected in only $11 \%$ of the investigated air samples. Based on the Chao- 1 index (Table S3), we obtained an estimate of $\sim 137$ OTUs for the actual species richness of archaea in the investigated air samples (see also Supplement for detailed discussion). This species richness is only about $50 \%$ of that reported by Brodie et al. (2007) for two urban sites in North America. However, in urban air, the composition and abundance of aerosol microbes seems to be unique. Bacteria, for instance, are often released from strong point sources (Després et al., 2012; Fang et al., 2007; Shaffer and Lighthart, 1997), and this may also be true for archaea. While the number of investigated samples and DNA amplification products used in this study certainly underestimates the actual diversity of archaea in air, Fröhlich-Nowoisky et al. (2009) detected 368 fungal species in a slightly smaller but otherwise identical data set.

\subsection{Seasonally and meteorologically derived dynamics of airborne archaea}

Seasonal variation within the species richness of Thaumarchaeota shows highest diversity in the fall/winter period is illustrated in Fig. 3a. The sampling site in Germany is situated in an area with extensive agriculture. After the harvest of particular grains or rapeseed at the end of summer, fields either remain bare over fall and winter or are prepared, for example, by plowing and tilling of the upper $10-30 \mathrm{~cm}$ for seeding. Soil turnover might influence the number of Thaumarchaeota available for aerosolization, as the surface soil is enriched with Thaumarchaeota, and their frequency decreases with depth (Jia and Conrad, 2009; Leininger et al., 2006).
As meteorological conditions are also known to influence airborne communities, we compared the statistical variance of archaeal diversity in relation to average wind speed, temperature, relative humidity, and the sum of precipitation, since temperature and relative humidity have already been found to correlate with airborne fungal composition (Fröhlich-Nowoisky et al., 2009). On a short-term samplewise basis, we found that the relative species diversity of archaea correlates significantly with wind speed (negative correlation, $p$ value $=0.01$; Table S6, Fig. S2a). On a long-term monthly basis, multiple linear correlation analysis revealed that the normalized species richness $\left(S_{n}\right.$; Fig. 4 a) negatively correlated with both temperature and wind speed, while the relative species richness ( $S_{R, k}$ Fig. 4b) showed a significant positive correlation with relative humidity and wind speed, although wind speed played a secondary role in both cases ( $p$ value $\left(S_{n}\right)=0.02$ and $\left(S_{R, k}\right)=0.01$ ). These findings coincide with our results that archaea diversity is highest in the fall/winter period, as temperature decreases during that time in the sampling regions. In fall and winter relative humidity also increases. At this point, however, no answer can be given regarding whether the meteorological factors are causing the diversity change, or whether the correlations are merely coincidental with the diversity and meteorology following similar annual cycle and other factors, e.g., increased aerosolization sources, cause the phenomenon. However, as illustrated in, for example, Fig. 4a between December 2006 and March 2007 , the successive steep rise and fall of $S_{n}$ is predicted rather accurately by the linear model, indicating that the correlation might not be coincidental.

Although $S_{n}$ stayed constant for Euryarchaeota throughout the year, the relative frequency of occurrence (RFO) that is, the proportion of samples in which these species 


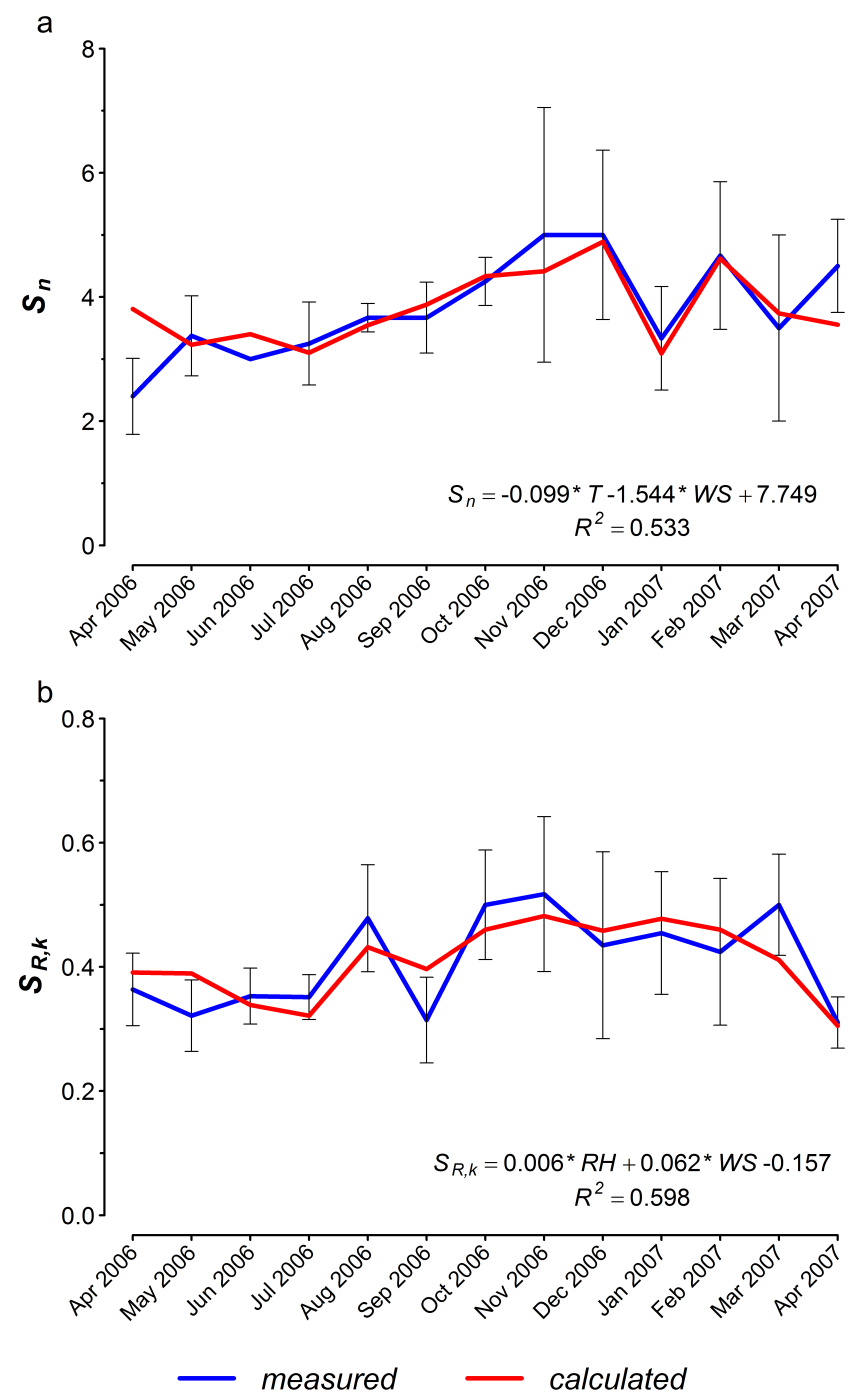

Figure 4. Time series depicting the most significant results from a multiple linear regression analysis between two diversity parameters - normalized species richness per month $\left(S_{n}\right)$ and relative species diversity per month $\left(S_{R, k}\right)$ - and meteorological factors. The observed $S_{n}$ and $S_{R, k}$ curves (blue) were calculated with the equations given in Table S3. The modeled $S_{n}$ and $S_{R, k}$ curves (red) were calculated using the monthly averages of the corresponding meteorological factors in the equations depicted in the plots. (a) Time series of $S_{n}$. Best variable subset: $T$ and $W S$ ( $p$ value $=0.011)$, with error bars being $S E_{n}\left(S_{n}\right)$. (b) Time series of $S_{R, k}$. Best variable subset: $R H$ and $W S$ ( $p$ value $=0.022$ ), with error bars being $S E_{n}\left(S_{R, k}\right) . R H$ : average relative humidity [\%]; WS: average wind speed $\left[\mathrm{m} \mathrm{s}^{-1}\right] ; T$ : average temperature $\left[{ }^{\circ} \mathrm{C}\right]$.

were detected - exhibited variations (Fig. 3b). In spring, Euryarchaeota were present in almost $50 \%$ of the air samples, while over the rest of the year they were found in only 20-30\% of them. A constant source of Euryarchaeota could be the nearby river Rhine, as Methanomicrobiales and Thermoplasmatales can be found in freshwater (Auguet et al.,

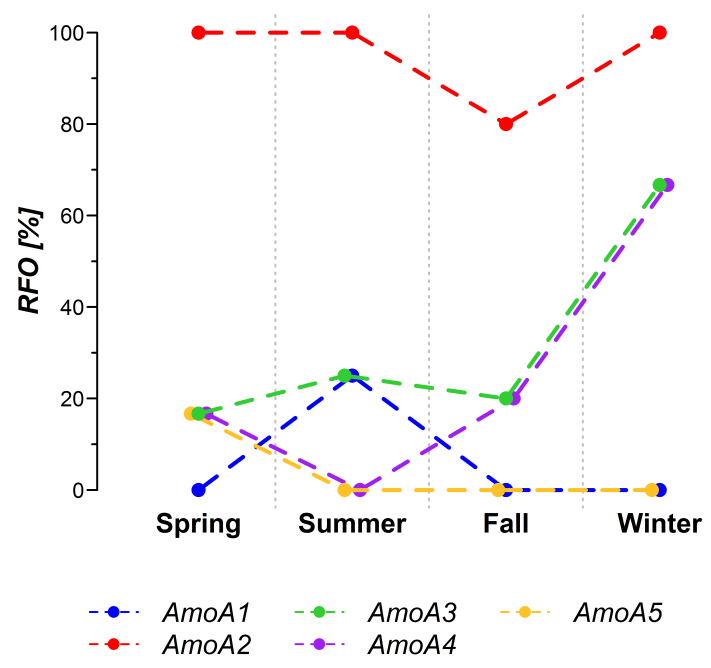

Figure 5. Seasonal variations in the relative frequency of occurrence (RFO) of the individual amoA OTUs detected in Mainz, Germany.

2010; Cao et al., 2013; Galand et al., 2006) and might thus be aerosolized. The increase in the RFO in spring may be linked to anthropogenic activities like fertilization of the soil. Although methanogens have been shown to be present in low numbers in aerated soils (Angel et al., 2012), the increase in the here-predicted methanogens in spring might be due to fields being fertilized with manure, and thus their methanogen composition may be affected (Gattinger et al., 2007; Nicol et al., 2003; Radl et al., 2007). All of the Euryarchaeota detected here are known to be common in livestock manure (St-Pierre and Wright, 2013).

\subsection{Ammonia-oxidizing archaea in air}

Within the air samples analyzed over a whole year, a total of five OTUs were discovered among the amoA gene sequences. As depicted in Fig. 5, two OTUs were present throughout the year, while the others were detected only sporadically. From comparison of the two most common OTUs, AmoA2 showed a high relative frequency of occurrence, while the other was always below $60 \%$. Within our air filter samples we found that the 16S rRNA gene OTU Archl and amoA OTU AmoA2 occur on $94 \%$ of the filter samples together, while no other OTUs showed such a high co-occurrence. This co-occurrence suggests that both genes may actually have been amplified from the same microorganisms. This observation confirms that the Nitrososphaera amoA cluster may be equivalent to the 16S rRNA cluster I.1b, as already indicated by other evidence (Bartossek et al., 2012; Pester et al., 2012).

The composition of amoA OTUs in the sampled air seems to be a combination of OTUs that are present throughout the year and others that occur only sporadically. OTUs that occur over the entire season might originate from a constant source like the river Rhine or sparsely vegetated soil, as it has been 
Table 2. Summary of published airborne archaea sequence information. Sampling location, the most likely source of the air masses, the number of reported OTUs, the information as to which archaeal phyla they were attributed to, and the sequencing technique performed. * Another study by Bowers et al. (2013) analyzed bacteria and fungi in air collected at the Colorado Front Range over a 14 month period with the Illumina HiSeq technique. Within this study, archaea were amplified as well; however, no detailed information is provided.

\begin{tabular}{|c|c|c|c|c|c|c|c|}
\hline Location & Air mass & OTUs & Euryarchaeota $(\%)$ & Thaumarchaeota $(\%)$ & Other $(\%)$ & Technique & Publication \\
\hline North America (Salt Lake City, Utah) & Continental & 3 & 0 & 100 & 0 & Sanger sequencing & Radosevich et al. (2002) \\
\hline Middle America (St Antonia \& Austin, Texas) & Continental/urban & 307 & 70 & 15 & 15 & Microarray & Brodie et al. (2007) \\
\hline Asia (East Korea) & Coastal & 1 & 100 & 0 & 0 & Sanger sequencing & Cho and Hwang (2011) \\
\hline North America (Mt. Bachelor) & Transpacific plume & 11 & 82 & 0 & 18 & Microarray & Smith et al. (2013) \\
\hline Asia (Beijing) & Maritime influence & - & 0.8 & - & - & Hiseq Illumina & Cao et al. (2014) \\
\hline Europe (Mainz, Germany) & Continental & 58 & 14 & 86 & 0 & Sanger sequencing & This study \\
\hline North America (Colorado) & Continental & 1 & 0 & 100 & 0 & Sanger sequencing & \\
\hline Africa (Cape Verde) & Coastal & 25 & 40 & 60 & 0 & Sanger sequencing & \\
\hline Europe (UK) & Coastal & 4 & 100 & 0 & 0 & Sanger sequencing & \\
\hline Asia (China) & Coastal & 1 & 100 & 0 & 0 & Sanger sequencing & \\
\hline
\end{tabular}

shown that AOA are present in rivers, freshwater environments, and soils (Cao et al., 2013; Liu et al., 2011; Pouliot et al., 2009). In contrast, OTUs that occur only sporadically might originate from unique sources like localized spreading of compost.

The presence of different amoA OTUs in air could indicate that air might serve as a medium to distribute AOA globally. In this case, fertilization, which is known to decrease AOA frequency and diversity in comparison to AOB (He et al., 2012; Xu et al., 2012), might also decrease the spreading of AOA to some extent.

\subsection{Comparison between locations}

Initial analyses suggest that the composition of airborne microorganisms shows biogeographic patterns, especially between continental, coastal, and marine sites, but also across different land-use types, though only a few studies have considered or attempted to study this phenomenon by means of molecular or cultural methods (e.g., Bovallius et al., 1978; Bowers et al., 2011; Després et al., 2007; Fröhlich-Nowoisky et al., 2012; Shaffer and Lighthart, 1997; Womack et al., 2010). The comparison between sampling sites can in general be challenging when different sampling and analysis procedures are used. Although the local geographic and meteorological conditions need to be taken into account in a comparison between sites, the height at which the samples were taken for this study is negligible as the continental boundary layer air up to $1000 \mathrm{~m}$ is fairly well mixed and various atmospheric measurements can be compared. We thus compared archaea diversity detected in the continental air of Mainz with the archaea diversity we discovered in an additional subset of 26 air filter samples from coastal air in Cape Verde, which were collected in winter 2011. The approximately $6 \mathrm{~m}$ difference in sampling height is negligible. The air of Cape Verde represents typical coastal air and is influenced by a combination of marine and continental air masses. The 72 sequences detected in Cape Verde air were separated into 25 different OTUs. Both Euryarchaeota and Thaumarchaeota were present (Fig. 1b, Table S5).
While $86 \%$ of the OTUs were Thaumarchaeota in Mainz, only $60 \%$ could be affiliated with this archaeal group in Cape Verde. Out of the Thaumarchaeota OTUs detected in Cape Verde, $73 \%$ were identical to OTUs detected in Mainz, and more than $50 \%$ were discovered in several air samples. This might imply that the airborne Thaumarchaeota of Cape Verde disperse on a larger scale. However, the few OTUs abundant in Germany were discovered only at the Mainz site. This might indicate that OTUs that are abundant and present throughout the year at this site are dispersed locally and do not originate from far away.

Euryarchaeota in Cape Verde were not very diverse and only contained Halobacteriales and Thermoplasmatales (Fig. 1b). In Germany, in addition to one OTU of Halobacteriales, different methanogens were found. The lack of methanogens in Cape Verde and the dominance of a limited set of Euryarchaeota may be due to the relatively stronger influence of the marine environment compared to terrestrial ecosystems impacted by small-scale agriculture. Interestingly, we did not find Euryarchaeota from the marine group II, which are typical for ocean surface layers (Galand et al., 2009; Hugoni et al., 2013; Massana et al., 1997). Although the results for Cape Verde are based on a preliminary data set only, our results might point to general differences in the composition of airborne archaea in continental versus coastal air.

To follow up on the hypothesis that the composition of airborne archaea depends on the type of ecosystem found beneath the air masses, samples from other continental and coastal sites were investigated. We successfully amplified archaea from 1 of 20 random filter samples taken in Colorado (Huffman et al., 2013). The 20 sequences obtained from this filter all fell into one OTU which was identical to the $16 \mathrm{~S}$ rRNA gene OTU Arch31, a Thaumarchaeota, also found in Mainz. In China and the United Kingdom we tried to amplify archaea 16S rRNA gene sequences from 14 and 12 filter samples, respectively, taken from coastal sites with influences from marine and continental air. We could only successfully amplify archaea 16S rRNA gene sequences from one filter sample at each site. All seven sequences from the 
Chinese site belonged to one OTU, which was identical to Arch16, a predicted methanogen, observed in Mainz air. In the UK sample set, we amplified 11 sequences from a filter on which primarily air masses from the North Sea were sampled (Gysel et al., 2007). These sequences grouped into four OTUs, all of which belonged to the order Thermoplasmatales (Euryarchaeota). These results support the observations from Cape Verde that the diversity of Euryarchaeota in coastal samples might be higher and their composition different compared to continental samples.

We also compared our results with the scarce literature available for airborne archaea (Table 2). Continental airborne archaea from Salt Lake City (Radosevich et al., 2002) belonged to Thaumarchaeota, supporting the hypothesis that Thaumarchaeota prevail in continental air. Using microarray techniques targeting 16S rRNA genes, Brodie et al (2007) counted, in two cities in Texas, $30 \%$ Crenarchaeota (under the assumption that these would be assigned to Thaumarchaeota in a reanalysis) and $70 \%$ Euryarchaeota. However, the influence of marine air from the nearby Gulf of Mexico cannot be judged. To our knowledge, there are no sequences of airborne archaea from coastal sites available in the literature. However, Cho et al. (2011) found one single archaea OTU in marine air from the East Sea (Korea), which was identified as belonging to the Halobacteriales (Euryarchaeota). Using microarrays, Smith et al. (2013) found within the very few archaea detected in air influenced by marine air masses that $82 \%$ of the OTUs belonged to the $E u$ ryarchaeota. As the number of available sequences and literature is limited, more analyses need to be done to confirm or reject the hypothesis about biogeography in airborne archaea.

\section{Conclusions}

With this study we gained first insights into the seasonal behavior of airborne archaea diversity, composition, and abundance in a continental, agriculture-dominated sampling site. The measured abundance of airborne archaea (1 to $1016 \mathrm{~S}$ rRNA gene copies per cubic meter of air) was much lower than the abundance of airborne bacteria $\left(10^{4}-10^{6} \mathrm{cp} \mathrm{m}^{-3}\right)$ and the ratio of archaea to bacteria was orders of magnitudes lower than in soil and marine environments. We show that the diversity of common soil Thaumarchaeota (I.1b), which are present throughout the year, correlates positively with relative humidity and negatively with temperature. This, together with the increased number of bare agricultural fields after harvest being available for aerosolization processes, may lead to the observed diversity peaks in fall and winter. In general, the diversity of the $a m o A$ gene was much lower than in the 16S rRNA gene. The OTU AmoAl correlates with Archl, the most abundant OTU from the $16 \mathrm{~S}$ region. This could point to associations of an $a m o A$ OTU with an archaeal 16S rRNA gene OTU. The few predicted methanogenic $E u$ - ryarchaeota found show no seasonal trends in diversity but a slightly increased relative frequency of occurrence in spring, when fields are fertilized with manure. The comparison of this continental site with airborne archaea at a coastal site in Cape Verde indicates differences in community composition and that the diversity of Euryarchaeota might increase in coastal air. These results were supported by data from additional sampling sites in the United Kingdom, China, and North America, and also concurred with the very limited information available in the literature.

We conclude that air as a transport medium might play an important role in habitat and niche formation for archaea. Thus, the analysis of archaea diversity, abundance, and composition in air is important in order to better understand their behavior and evolutionary history in their primary ecosystems.

\section{The Supplement related to this article is available online at doi:10.5194/bg-11-6067-2014-supplement.}

Acknowledgements. We thank T. Andreae, R. Burgess, R. Garland, M. Grant, A. Huffman, M. Klose, C. Pöhlker, D. Rose, B. Schmer, B. Schmitt, and H. Yang for technical assistance, as well as H. Paulsen and Z. Jia for helpful discussions. This work was funded by the Max Planck Society, the German Research Foundation (DE1161/2-1, PO1013/5-1, FOR 1525 INUIT), the LEC Geocycles in Mainz funded by the state Rhineland-Palatinate, and the Portuguese Science Foundation through the project PTDD/AACCLI/100331/2008 (CV-Dust). J. Cardoso acknowledges the PhD grant SFRH-BD-6105-2009 from FCT. P. E. Galand is supported by the Agence Nationale de la Recherche (ANR) project MICADO (ANR-11JSSV7-003-01).

The service charges for this open access publication have been covered by the Max Planck Society.

Edited by: J. Middelburg 


\section{References}

Angel, R., Claus, P., and Conrad, R.: Methanogenic archaea are globally ubiquitous in aerated soils and become active under wet anoxic conditions, ISME J., 6, 847-862, 2012.

Auguet, J.-C., Barberan, A., and Casamayor, E. O.: Global ecological patterns in uncultured Archaea, ISME J., 4, 182-190, 2010.

Baertsch, C., Paez-Rubio, T., Viau, E., and Peccia, J.: Source tracking aerosols released from land-applied class B biosolids during high-wind events, Appl. Environ. Microb., 73, 4522-4531, 2007.

Baker, G. C. and Cowan, D.: $16 \mathrm{~S}$ rDNA primers and the unbiased assessment of thermophile diversity, Biochem. Soc. T., 32, 218-221, 2004.

Bartossek, R., Spang, A., Weidler, G., Lanzen, A., and Schleper, C.: Metagenomic analysis of ammonia-oxidizing archaea affiliated with the soil group, Front. Microbiol., 3, 208, doi:10.3389/fmicb.2012.00208, 2012.

Bates, S. T., Berg-Lyons, D., Caporaso, J. G., Walters, W. A., Knight, R., and Fierer, N.: Examining the global distribution of dominant archaeal populations in soil, ISME J., 5, 908-917, 2011.

Bintrim, S. B., Donohue, T. J., Handelsman, J., Roberts, G. P., and Goodman, R. M.: Molecular phylogeny of Archaea from soil, P. Natl Acad. Sci. USA., 94, 277-282, 1997.

Boetius, A., Ravenschlag, K., Schubert, C. J., Rickert, D., Widdel, F., Gieseke, A., Amann, R., Jørgensen, B. B., Witte, U., and Pfannkuche, O.: A marine microbial consortium apparently mediating anaerobic oxidation of methane, Nature, 407, 623-626, 2000.

Bovallius, A., Bucht, B., Roffey, R., and Anäs, P.: Long-range air transmission of bacteria, Appl. Environ. Microbiol., 35, 1231-1232, 1978.

Bowers, R. M., Lauber, C. L., Wiedinmyer, C., Hamady, M., Hallar, A. G., Fall, R., Knight, R., and Fierer, N.: Characterization of airborne microbial communities at a high-elevation site and their potential to act as atmospheric ice nuclei, Appl. Environ. Microb., 75, 5121-5130, 2009.

Bowers, R. M., McLetchie, S., Knight, R., and Fierer, N.: Spatial variability in airborne bacterial communities across land-use types and their relationship to the bacterial communities of potential source environments, ISME J., 5, 601-612, 2011.

Bowers, R. M., Clements, N., Emerson, J. B., Wiedinmyer, C., Hannigan, M. P., and Fierer, N.: Seasonal variability in bacterial and fungal diversity of the near-surface atmosphere, Environ. Sci. Technol., 47, 12097-12106, 2013.

Brochier-Armanet, C., Boussau, B., Gribaldo, S., and Forterre, P.: Mesophilic Crenarchaeota: proposal for a third archaeal phylum, the Thaumarchaeota, Nat. Rev. Microbiol., 6, 245-252, 2008.

Brochier-Armanet, C., Forterre, P., and Gribaldo, S.: Phylogeny and evolution of the Archaea: one hundred genomes later, Curr. Opin. Microbiol., 14, 274-281, 2011.

Brodie, E. L., DeSantis, T. Z., Parker, J. P. M., Zubietta, I. X., Piceno, Y. M., and Andersen, G. L.: Urban aerosols harbor diverse and dynamic bacterial populations, P. Natl. Acad. Sci. USA., 104, 299-304, 2007.

Burggraf, S., Huber, H., and Stetter, K. O.: Reclassification of the Crenarchaeal Orders and Families in Accordance with 16S rRNA Sequence Data, Int. J. Syst. Bacteriol., 47, 657-660, 1997.

Burrows, S. M., Butler, T., Jöckel, P., Tost, H., Kerkweg, A., Pöschl, U., and Lawrence, M. G.: Bacteria in the global atmosphere -
Part 2: Modeling of emissions and transport between different ecosystems, Atmos. Chem. Phys., 9, 9281-9297, 2009, http://www.atmos-chem-phys.net/9/9281/2009/.

Cao, C., Jiang, W., Wang, B., Fang, J., Land, J., Tian, G., Jingkun, J., and Zhu, T. F.: Inhalable microorganisms in Beijing's PM2.5 and PM10 pollutants during a severe smog event., Environ. Sci. Technol., 48, 1499-1507, 2014.

Cao, H., Dang, H., and Gu, J.-D.: Responses of aerobic and anaerobic ammonia/ammonium- oxidizing microorganisms to anthropogenic pollution in coastal marine environments, Methods Enzymol., 496, 35-62, 2011.

Cao, H., Auguet, J.-C., and Gu, J.-D.: Global Ecological Pattern of Ammonia-Oxidizing Archaea, edited by: Bertilsson, S., PLoS One, 8, 1-8, 2013.

Cao, P., Zhang, L., Shen, J., Zheng, Y.-M., Hong, J. D., and He, J.Z.: Distribution and diversity of archaeal communities in selected Chinese soils, FEMS Microbiol. Ecol., 80, 146-158, 2012.

Cavicchioli, R.: Archaea- timeline of the third domain, Nat. Rev. Microbiol., 9, 51-61, 2011.

Cho, B. C. and Hwang, C. Y.: Prokaryotic abundance and 16S rRNA gene sequences detected in marine aerosols on the East Sea (Korea), FEMS Microbiol. Ecol., 76, 327-341, 2011.

DeLong, E. F.: Archaea in coastal marine environments., P. Natl. Acad. Sci. USA., 89, 5685-5689, 1992.

Després, V. R., Nowoisky, J. F., Klose, M., Conrad, R., Andreae, M. O., and Pöschl, U.: Characterization of primary biogenic aerosol particles in urban, rural, and high-alpine air by DNA sequence and restriction fragment analysis of ribosomal RNA genes, Biogeosciences, 4, 1127-1141, doi:10.5194/bg-4-1127-2007, 2007.

Després, V. R., Huffman, A. J., Burrows, S. M., Hoose, C., Safatov, A. S., Buryak, G., Fröhlich-Nowoisky, J., Elbert, W., Andreae, M. O., Pöschl, U., and Jaenicke, R.: Primary biological aerosol particles in the atmosphere: a review, Tellus B, 64, 15598, doi:10.3402/tellusb.v64i0.15598, 2012.

Edgar, R. C.: MUSCLE: a multiple sequence alignment method with reduced time and space complexity, BMC Bioinformatics, 5, 113, doi:10.1186/1471-2105-5-113, 2004.

Edgar, R. C.: Search and clustering orders of magnitude faster than BLAST, Bioninformatics, 26, 2460-2461, 2010.

Falkowski, P. G., Fenchel, T., and Delong, E. F.: The microbial engines that drive Earth's biogeochemical cycles, Science, 320, 1034-1039, 2008.

Fang, Z., Ouyang, Z., Zheng, H., Wang, X., and Hu, L.: Culturable airborne bacteria in outdoor environments in Beijing, China, Microb. Ecol., 54, 487-496, 2007.

Fierer, N., Liu, Z., Rodríguez-Hernández, M., Knight, R., Henn, M., and Hernandez, M. T.: Short-term temporal variability in airborne bacterial and fungal populations, Appl. Environ. Microb., 74, 200-207, 2008.

Fröhlich-Nowoisky, J., Pickersgill, D. A., Després, V. R., and Pöschl, U.: High diversity of fungi in air particulate matter, P. Natl. Acad. Sci. USA., 106, 12814-12819, 2009.

Fröhlich-Nowoisky, J., Burrows, S. M., Xie, Z., Engling, G., Solomon, P. A., Fraser, M. P., Mayol-Bracero, O. L., Artaxo, P., Begerow, D., Conrad, R., Andreae, M. O., Després, V. R., and Pöschl, U.: Biogeography in the air: fungal diversity over land and oceans, Biogeosciences, 9, 1125-1136, doi:10.5194/bg9-1125-2012, 2012. 
Galand, P., Lovejoy, C., and Vincent, W.: Remarkably diverse and contrasting archaeal communities in a large arctic river and the coastal Arctic Ocean, Aquat. Microb. Ecol., 44, 115-126, 2006.

Galand, P. E., Casamayor, E. O., Kirchman, D. L., Potvin, M., and Lovejoy, C.: Unique archaeal assemblages in the Arctic Ocean unveiled by massively parallel tag sequencing, ISME J., 3, 860-869, 2009.

Gattinger, A., Höfle, M. G., Schloter, M., Embacher, A., Böhme, F., Munch, J. C., and Labrenz, M.: Traditional cattle manure application determines abundance, diversity and activity of methanogenic Archaea in arable European soil, Environ. Microbiol., 9, 612-624, 2007.

Grosskopf, R., Janssen, P. H., and Liesack, W.: Diversity and structure of the methanogenic community in anoxic rice paddy soil microcosms as examined by cultivation and direct $16 \mathrm{~S}$ rRNA gene sequence retrieval, Appl. Environ. Microb., 64, 960-969, 1998.

Gruber, N. and Galloway, J. N.: An Earth-system perspective of the global nitrogen cycle, Nature, 451, 293-296, 2008.

Gysel, M., Crosier, J., Topping, D. O., Whitehead, J. D., Bower, K. N., Cubison, M. J., Williams, P. I., Flynn, M. J., McFiggans, G. B., and Coe, H.: Closure study between chemical composition and hygroscopic growth of aerosol particles during TORCH2, Atmos. Chem. Phys., 7, 6131-6144, doi:10.5194/acp-7-61312007, 2007.

He, J.-Z., Hu, H.-W., and Zhang, L.-M.: Current insights into the autotrophic thaumarchaeal ammonia oxidation in acidic soils, Soil Biol. Biochem., 55, 146-154, 2012.

Huber, T., Faulkner, G., and Hugenholtz, P.: Bellerophon: a program to detect chimeric sequences in multiple sequence alignments, Bioinformatics, 20, 2317-2319, 2004.

Huffman, J. A., Prenni, A. J., DeMott, P. J., Pöhlker, C., Mason, R. H., Robinson, N. H., Fröhlich-Nowoisky, J., Tobo, Y., Després, V. R., Garcia, E., Gochis, D. J., Harris, E., Müller-Germann, I., Ruzene, C., Schmer, B., Sinha, B., Day, D. A., Andreae, M. O., Jimenez, J. L., Gallagher, M., Kreidenweis, S. M., Bertram, A. K., and Pöschl, U.: High concentrations of biological aerosol particles and ice nuclei during and after rain, Atmos. Chem. Phys., 13, 6151-6164, doi:10.5194/acp-13-6151-2013, 2013.

Hugoni, M., Taib, N., Deboras, D., Domaizon, I., Dufournel, I. J., Bronner, G., Salter, I., Agogúe, H., Mary, I., and Galand, P. E.: Sturcture of the rare archaeal biosphere and seasonal dynamics of active ecotypes in surface coastal waters, P. Natl. Acad. Sci. USA, 110, 6004-6009, 2013.

Jia, Z. and Conrad, R.: Bacteria rather than Archaea dominate microbial ammonia oxidation in an agricultural soil, Environ. Microbiol., 11, 1658-1671, 2009.

Jones, A. M. and Harrison, R. M.: The effects of meteorological factors on atmospheric bioaerosol concentrations-a review, Sci. Total Environ., 326, 151-180, 2004.

Junier, P., Molina, V., Dorador, C., Hadas, O., Kim, O.-S., Junier, T., Witzel, J.-P., and Imhoff, J. F.: Phylogenetic and functional marker genes to study ammonia-oxidizing microorganisms (AOM) in the environment, Appl. Microbiol. Biot., 85, 425-440, 2010.

Jurgens, G., Glöckner, F.-O., Amann, R., Saano, A., Montonen, L., Likolammi, M., and Münster, U.: Identification of novel Archaea in bacterioplankton of a boreal forest lake by phylogenetic analy- sis and fluorescent in situ hxbridization, FEMS Microbiol. Ecol., 34, 45-56, 2000.

Karner, M. B., DeLong, E. F., and Karl, D. M.: Archaeal dominance in the mesopelagic zone of the Pacific Ocean., Nature, 409, 507-510, 2001.

Kemnitz, D., Kolb, S., and Conrad, R.: High abundance of Crenarchaeota in a temperate acidic forest soil., FEMS Microbiol. Ecol., 60, 442-448, 2007.

Kowalchuk, G. A. and Stephen, J. R.: Ammonia-oxidizing bacteria: a model for molecular microbial ecology, Annu. Rev. Microbiol., 55, 485-529, 2001.

Lane, D. J.: 16S/23S rRNA sequencing, in Nucleic acid techniques in bacterial systematics, edited by: Stackebrandt, E. and Goodfello, M., Wiley, Chichester, 205-248, 1991.

Leininger, S., Schloter, M., Schwark, L., Qi, J., Nicol, G. W., Prosser, J. I., Schuster, S. C., and Schleper, C.: Archaea predominate among ammonia-oxidizing prokaryotes in soils, Nature, 442, 806-809, 2006.

Lighthart, B. and Shaffer, B. T.: Airborne Bacteria in the Atmospheric Surface Layer: Temporal Distribution above a Grass Seed Field, Appl. Environ. Microb., 61, 1492-1496, 1995.

Liu, Z., Huang, S., Sun, G., Xu, Z., and Xu, M.: Diversity and abundance of ammonia-oxidizing archaea in the Dongjiang River, China, Microbiol. Res., 166, 337-345, 2011.

Lueders, T., Manefield, M., and Friedrich, M. W.: Enhanced sensitivity of DNA- and rDNA-based stable isotope probing by fractionation and quantitative analysis of isopycnic centrifugation gradients, Environ. Microbiol., 6, 73-78, 2004.

Massana, R., Murray, a E., Preston, C. M., and DeLong, E. F.: Vertical distribution and phylogenetic characterization of marine planktonic Archaea in the Santa Barbara Channel, Appl. Environ. Microb., 63, 50-56, 1997.

Moletta, M., Delgenes, J.-P., and Godon, J.-J.: Differences in the aerosolization behavior of microorganisms as revealed through their transport by biogas, Sci. Total Environ., 379, 75-88, 2007.

Neter, J., Kutner, M., and Wasserman, W.: Applied linear statistical models, 4th ed., edited by Irwin, McGraw-Hill, Irwin, Chicago, 1996.

Nicol, G. W., Glover, L. A., and Prosser, J. I.: Molecular analysis of methanogenic archaeal communities in managed and natural upland pasture soils, Glob. Chang. Biol., 9, 1451-1457, 2003.

Ochsenreiter, T., Selezi, D., Quaiser, A., Bonch-Osmolovskaya, L., and Schleper, C.: Diversity and abundance of Crenarchaeota in terrestrial habitats studied by $16 \mathrm{~S}$ RNA surveys and real time PCR, Environ. Microbiol., 5, 787-797, 2003.

Offre, P., Spang, A., and Schleper, C.: Archaea in biogeochemical cycles, Annu. Rev. Microbiol., 67, 437-457, 2013.

Pester, M., Schleper, C., and Wagner, M.: The Thaumarchaeota?: an emerging view of their phylogeny and ecophysiology, Curr. Opin. Microbiol., 14, 300-306, 2011.

Pester, M., Rattei, T., Flechl, S., Gröngröft, A., Richter, A., Overmann, J., Reinhold-Hurek, B., Loy, A., and Wagner, M.: amoAbased consensus phylogeny of ammonia-oxidizing archaea and deep sequencing of amoA genes from soils of four different geographic regions, Environ. Microbiol., 14, 525-539, 2012.

Pouliot, J., Galand, P. E., Lovejoy, C., and Vincent, W. F.: Vertical structure of archaeal communities and the distribution of ammonia monooxygenase A gene variants in two meromictic High Arctic lakes, Environ. Microbiol., 11, 687-699, 2009. 
Prospero, J. M., Blades, E., Mathison, G., and Naidu, R.: Interhemispheric transport of viable fungi and bacteria from Africa to the Caribbean with soil dust, Aerobiologia (Bologna), 21, 1-19, 2005.

Pruesse, E., Peplies, J., and Glöckner, F. O.: SINA: Accurate high-throughput multiple sequence alignment of ribosomal RNA genes, Bioinformatics, 28, 1823-1829, 2012.

Radl, V., Gattinger, A., Chronáková, A., Nemcová, A., Cuhel, J., Simek, M., Munch, J. C., Schloter, M., and Elhottová, D.: Effects of cattle husbandry on abundance and activity of methanogenic archaea in upland soils, ISME J., 1, 443-452, 2007.

Radosevich, J. L., Wilson, W. J., Shinn, J. H., DeSantis, T. Z., and Andersen, G. L.: Development of a high-volume aerosol collection system for the identification of air-borne micro-organisms, Lett. Appl. Microbiol., 34, 162-167, 2002.

R Development Core Team: R: A language and environment for statistical computing, reference index version 2.2.1, R Foundation for statistical computing, Vienna, 2005.

Robertson, C. E., Baumgartner, L. K., Harris, J. K., Peterson, K. L., Stevens, M. J., Frank, D. N., and Pace, N. R.: Cultureindependent analysis of aerosol microbiology in a metropolitan subway system, Appl. Environ. Microb., 79, 3485-3493, 2013.

Schleper, C. and Nicol, G. W.: Ammonia-oxidising archaeaphysiology, ecology and evolution, Adv. Microb. Ecol., 57, 1-41, 2010.

Schleper, C., Holben, W., and Klenk, H. P.: Recovery of crenarchaeotal ribosomal DNA sequences from freshwater-lake sediments, Appl. Environ. Microb., 63, 321-323, 1997.

Schleper, C., Jurgens, G., and Jonuscheit, M.: Genomic studies of uncultivated archaea, Nat. Rev. Microbiol., 3, 479-488, 2005.

Schloss, P. D., Westcott, S. L., Ryabin, T., Hall, J. R., Hartmann, M., Hollister, E. B., Lesniewski, R. A., Oakley, B. B., Parks, D. H., Robinson, C. J., Sahl, J. W., Stres, B., Thallinger, G. G., Van Horn, D. J., and Weber, C. F.: Introducing mothur: Open-Source, Platform-Independent, Community-Supported Software for Describing and Comparing Microbial Communities, Appl. Environ. Microb., 75, 7437-7541, 2009.

Shaffer, B. and Lighthart, B.: Survey of Culturable Airborne Bacteria at Four Diverse Locations in Oregon: Urban, Rural, Forest, and Coastal, Microb. Ecol., 34, 167-177, 1997.

Smith, D. J., Timonen, H. J., Jaffe, D. A., Griffin, D. W., Birmele, M. N., Perry, K. D., Ward, P. D., and Roberts, M. S.: Intercontinental dispersal of bacteria and archaea by transpacific winds, Appl. Environ. Microb., 79, 1134-1139, 2013.

Solomon, P. A., Moyers, J. L., and Fletcher, R. A.: High-Volume Dichotomous Virtual Impactor for the Fractionation and Collection of Particles According to Aerodynamic Size, Aerosol. Sci. Tech., 2, 455-464, 1983.

Stackebrandt, E. and Goebel, B. M.: Taxonomic Note: A Place for DNA-DNA Reassociation and 16S rRNA Sequence Analysis in the Present Species Definition in Bacteriology, Int. J. Syst. Bacteriol., 44, 846-849, 1994.

St-Pierre, B. and Wright, A.-D. G.: Diversity of gut methanogens in herbivorous animals, Animal, 7, 49-56, 2013.

Stubner, S.: Enumeration of $16 \mathrm{~S}$ rDNA of Desulfotomaculum lineage 1 in rice field soil by real-time PCR with SybrGreen detection, J. Microbiol. Meth., 50, 155-164, 2002.
Takai, K. E. N., Moser, D. P., Flaun, M. D. E., Onstott, T. C., and Fredrickson, J. K.: Archaeal Diversity in Waters from Deep South African Gold Mines, Appl. Environ. Microb., 67, 5750-5760, 2001.

Tamura, K., Peterson, D., Peterson, N., Stecher, G., Nei, M., and Kumar, S.: MEGA5: molecular evolutionary genetics analysis using maximum likelihood, evolutionary distance, and maximum parsimony methods, Mol. Biol. Evol., 28, 2731-2739, 2011.

Thummes, K., Kämpfer, P., and Jäckel, U.: Temporal change of composition and potential activity of the thermophilic archaeal community during the composting of organic material, Syst. Appl. Microbiol., 30, 418-429, 2007.

Treusch, A. H., Leininger, S., Kletzin, A., Schuster, S. C., Klenk, H.-P., and Schleper, C.: Novel genes for nitrite reductase and Amo-related proteins indicate a role of uncultivated mesophilic crenarchaeota in nitrogen cycling, Environ. Microbiol, 7, 1985-1995, 2005.

Wani, A. A., Surakasi, V. P., Siddharth, J., Raghavan, R. G., Patole, M. S., Ranade, D., and Shouche, Y. S.: Molecular analyses of microbial diversity associated with the Lonar soda lake in India: an impact crater in a basalt area, Res. Microbiol., 157, 928-937, 2006.

Whelan, S. and Goldman, N.: A general empirical model of preotein evolution derived from multiple protein families using a maximum-likelihood approach., Mol. Biol. Evol., 18, 691-699, 2001.

Woese, C. R., Kandler, O., and Wheelis, M. L.: Towards a natural system of organisms: Proposal for the domains Archaea, Bacteria, and Eucarya, P. Natl. Acad. Sci. USA, 87, 4576-4579, 1990.

Womack, A. M., Bohannan, B. J. M., and Green, J. L.: Biodiversity and biogeography of the atmosphere, Phil. Trans. R. Soc. B, 365, 3645-3653, 2010.

Woo, A. C., Brar, M. S., Chan, Y., Lau, M. C. Y., Leung, F. C. C., Scott, J. A., Vrijmoed, L. L. P., Zawar-Reza, P., and Pointing, S. B.: Temporal variation in airborne microbial populations and microbially-derived allergens in a tropical urban landscape, Atmos. Environ., 74, 291-300, 2013.

Woo, C. A.: Molecular ecology and public health risks of urban bioaerosols, 1-119, The University of Hong Kong, 2012.

$\mathrm{Xu}, \mathrm{Y} ., \mathrm{Yu}, \mathrm{W} ., \mathrm{Ma}, \mathrm{Q}$., and Zhou, H.: Responses of bacterial and archaeal ammonia oxidisers of an acidic luvisols soil to different nitrogen fertilization rates after 9 years, Biol. Fert. Soils, 48, 827-837, 2012.

Yamashita, T., Yamashita, K., and Kamimura, R.: A Stepwise AIC Method for Variable Selection in Linear Regression, Commun. Stat. - Theory Methods, 36, 2395-2403, 2007.

Yin, Q., Fu, B., Li, B., Shi, X., Inagaki, F., and Zhang, X.-H.: Spatial variations in microbial community composition in surface seawater from the ultra-oligotrophic center to rim of the South Pacific Gyre, PLoS One, 8, e55148, doi:10.1371/journal.pone.0055148, 2013.

Yooseph, S., Andrews-Pfannkoch, C., Tenney, A., McQuaid, J., Williamson, S., Thiagarajan, M., Brami, D., Zeigler-Allen, L., Hoffman, J., Goll, J. B., Fadrosh, D., Glass, J., Adams, M. D., Friedman, R., and Venter, J. C.: A metagenomic framework for the study of airborne microbial communities, PLoS One, 8, e81862, doi:10.1371/journal.pone.0081862, 2013. 